\title{
鉄骨部材がアンカーボルトを介して鉄筋コンクリート部材に結合される 卜字形接合部の耐力評価法に関する研究 STRENGTH EVALUATION OF JOINT S MEMBER WITH REINFORCED CONCRETE MEMBER USING ANCHOR BOLT
}

馬場 望*，金井真一**，西村泰志***

Nozomu BABA, Shinichi KANAI and Yasushi NISHIMURA

\begin{abstract}
The purpose of this study is to clarify stress transferring mechanism and strength evaluation of the joint connected steel member with reinforced concrete member using anchor bolt based on stress transfer from steel member and reinforced concrete member. To clarify stress transferring mechanism of the joint connected steel member with reinforced concrete member using anchor bolt, seven T-shaped assemblages were tested under monotonic loading. From the test results, it was shown that stress transfer from steel member to reinforced concrete member in the joint could be mobilized by transverse reinforcements arranged intensively around anchor bolt. Based on the arch mechanism and the truss mechanism, a method capable of estimating the ultimate strength of the joint was proposed. The predictions were shown to be in good agreement with the test results. In addition, it was shown that this proposed strength model could apply to the ultimate strength evaluation of the exterior beam-column joint using mechanical anchorages on the reinforced concrete structure.
\end{abstract}

Keywords : Composite structure, Exterior joint, Anchor bolt, Strength evaluation, Mechanical anchorages 合成構造，卜字形接合部，アンカーボルト，耐力評価法，機械式定着

\section{1. はじめに}

鋼コンクリート合成構造接合部の一つに, 鉄骨（以下， S という） 部材がアンカーボルト等を介して鉄筋コンクリート（以下， RC と いう）部材に結合される接合部がある。代表的な部位として， S 造 露出柱脚が挙げられる。また, 機械式定着工法を用いた RC 造柱梁 接合部は，定着筋をアンカーボルトと見なせば同種の接合部とみな すことができ，力学的な観点から見れば，これらの接合部の基本的 な応力伝達および抵抗機構は同じである。したがって, 接合部の基 本的な抵抗機構を明らかにすることによって, 従来の構造形式や部 位に依らず，ある程度基本的かつ統一的な接合部の終局耐力評価法 を構築することも可能である。しかしながら, 例えば $\mathrm{S}$ 造露出柱脚 において, ベースプレートやアンカーボルトに作用寸る応力につい ては設計指針 1) に示されているが，これらの応力が $\mathrm{RC}$ 部材に伝達 される機構や接合部の抵抗機構については示されていない。

このような観点から，本研究は， $\mathrm{S}$ 部材がアンカーボルトを介し て RC 部材に結合される接合部（以下，単に非埋込み接合部という） について, 図 1 に示すようなト字形接合部に着目して, S 部材から

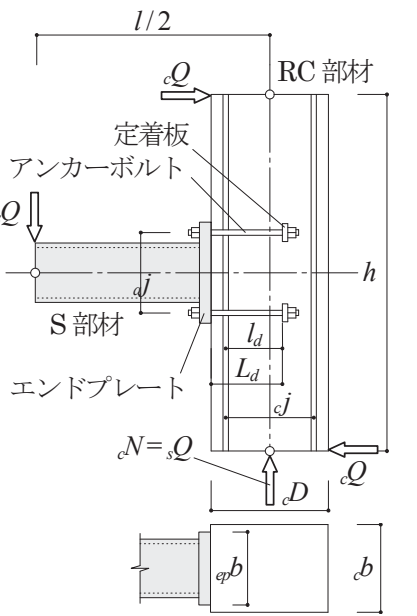

【記号】

${ }_{c} b: \mathrm{RC}$ 部材の幅

${ }_{e p} b:$ エンドプレートの幅

${ }_{c} D: \mathrm{RC}$ 部材のせい

$h: \mathrm{RC}$ 部材の反曲点間距離

$a j:$ アンカーボルトの重心

間距離

$c j$ : 主筋の重心間距離

$L_{d}$ :アンカーボルトの埋込 み長さ

$l_{d}$ : 定着板から主筋重心ま での距離

$l: \mathrm{S}$ 部材の反曲点間距離
* 大阪工業大学工学部建築学科 准教授 $\cdot$ 工博

** 繁建築構造設計事務所 工修

*** 大阪工業大学工学部建築学科 教授 $\cdot$ 工博
Assoc. Prof., Dept. of Architecture, Faculty of Engineering, Osaka Institute of Technology, Dr. Eng.

Shigeru Structural Engineers, M. Eng.

Prof., Dept. of Architecture, Faculty of Engineering, Osaka Institute of Technology, Dr. Eng. 
た，本終局耐力評価法を用いて，機械式定着工法を用いた $\mathrm{RC}$ 造柱 梁接合部の終局耐力の評価を試みる。

なお，本論文は，文献 2)を基に加筆してまとめたものである。

\section{2. 接合部の応力伝達機構および抵抗機構}

図 2 に下字形非埋込み接合部の基本的な応力伝達機構および抵抗 機構を示す。本研究で対象とする接合部ディテールは, 最も基本的 な観点から, RC 部材のせん断補強筋のみが配置されている単純な ディテールである。また, $\mathrm{S}$ 部材に引張軸力が作用する場合, 図 2 に示される接合部の応力伝達機構および抵抗機構とは異なる機構が 形成されるため, ここでは考慮しない。

$\mathrm{S}$ 部材に圧縮軸力, 曲げモーメントおよびせん断力が作用すると, エンドプレートの圧縮側では圧縮応力 $C$ とそれに伴う摩擦力, 引張 側ではアンカーボルトを介して定着板に支圧応力が作用し, これら の応力は反作用として $\mathrm{RC}$ 部材に伝達される。アンカーボルトの埋 込み長さ $L_{d}$ が $\mathrm{RC}$ 部材の有効せい $d$ 程度（以下， $L_{d} \fallingdotseq d$ とする) の 場合, 図 2(a)に示すように, A (B) 点では, 接合部パネルのコンク リート圧縮束に作用寸る圧縮力 $R_{p}, \mathrm{RC}$ 部材接合端に作用する曲げ 圧縮力 ${ }_{c} C_{a}$ とせん断力 ${ }_{c} Q_{a}$ および定着板に作用寸る支圧応力 (エンド
プレート下面に作用する圧縮応力 $\left.C_{a}\right)$ によって釣合系を構成し，接 合部ではアーチ機構が形成されると考えられる。また，アンカーボ ルトの引張力 $T_{t}$ およびエンドプレートの圧縮応力 $C_{t}$ の反力は, $\mathrm{RC}$ 部材断面の隅角部に配置された主筋に向かう力となり，せん断補強 筋の引張力 ${ }_{p} T_{w}$ として伝達される。この応力伝達によって, ${ }_{p} T_{w}$ は主 筋の付着力およびコンクリート圧縮束に作用する圧縮力と釣合系を 構成し, トラス機構が形成されると考えられる。

しかしながら, アンカーボルトの埋込み長さ $L_{d}$ がRC部材の有効せ いdより小さい（以下， $L_{d}<d$ とする）場合，定着板高さ位置近傍で は，RC部材に大きな軸方向力が作用しない限り，接合部コンクリー 卜は RC部材接合端に作用する曲げ圧縮力による拘束力を期待する ことができない。この場合, 図2(b)に示寸ように, アンカーボルト の引張力 $T_{a}$ を介して定着板に作用する支圧応力の反力は, その作用 位置から $45^{\circ}$ 方向に想定された破壞面内において, 破壊面内を貫通 するRC部材側のせん断補強筋に引張力 ${ }_{c} T_{w}$ を生じさせる。したがっ て, 図中のA点において, ${ }_{c} T_{w}$, 主筋の付着力および圧縮力 ${ }_{c} C_{a}$ とせ し断力 ${ }_{c} Q_{a}$ の合力の反力は, 接合部のコンクリート圧縮束を介してエ ンドプレート圧縮側のB点に伝達され，接合部はアーチ機構を形成 寸ると考えられる。なお，上述の応力伝達に対して， $\mathrm{RC}$ 部材側の破
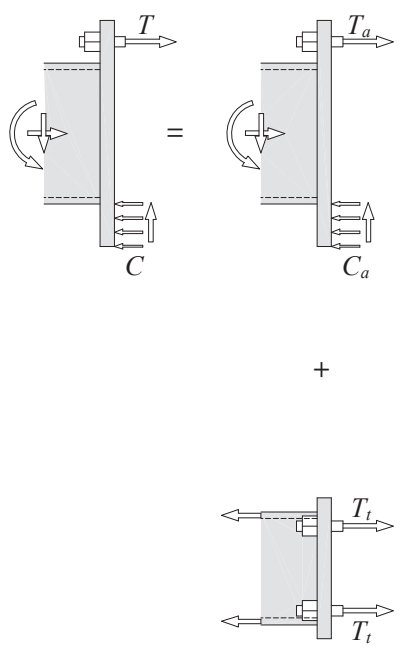

$$
{ }_{c} C_{a}
$$
$\left.{ }_{c} C_{a}\right]_{c} Q$

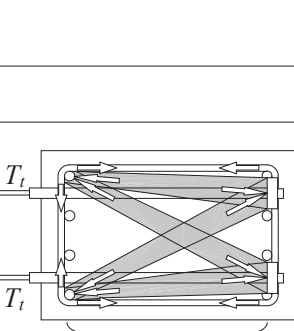
${ }_{p} T_{w}$
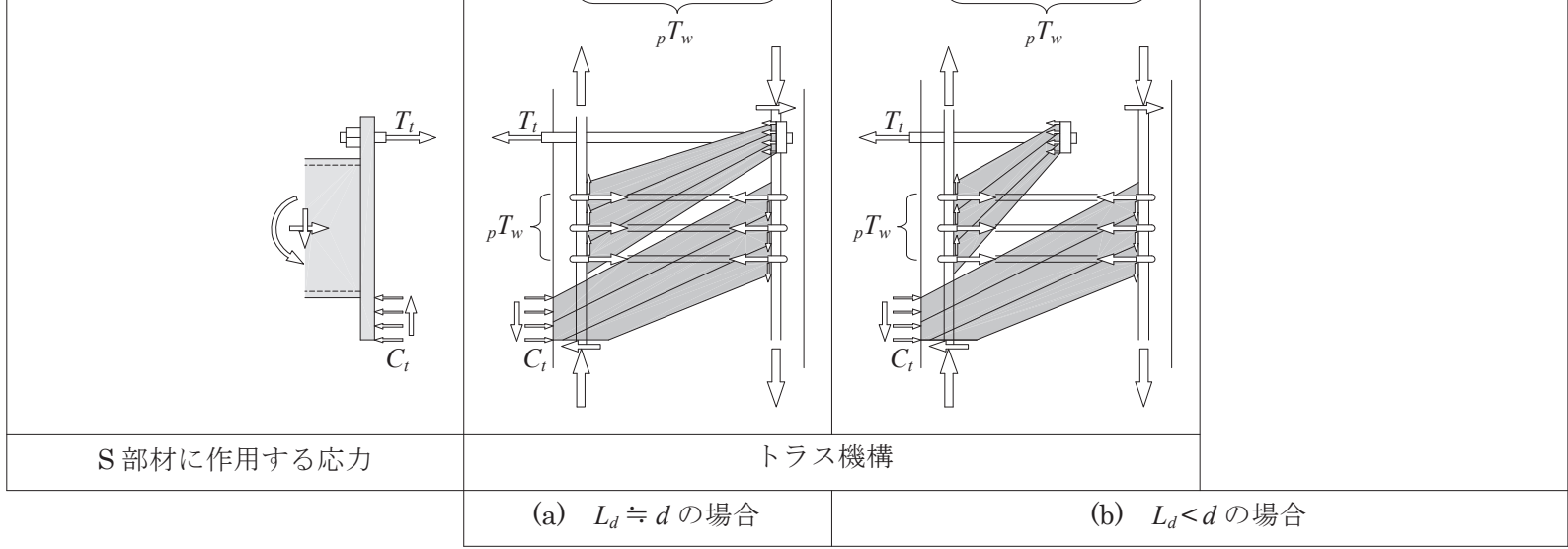

$\mathrm{A}$

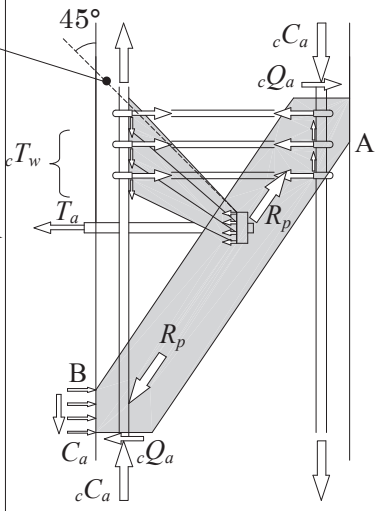

$Q_{a}$

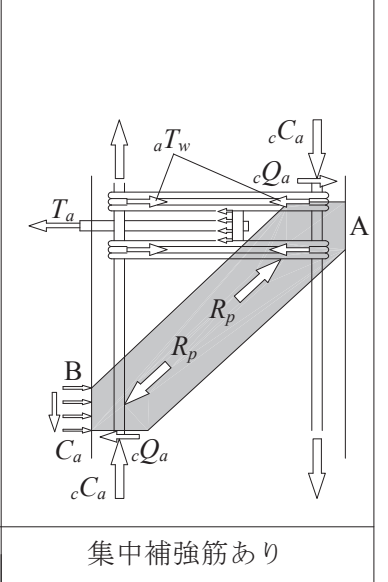

図 2 非埋込み接合部の応力伝達機構および抵抗機構 


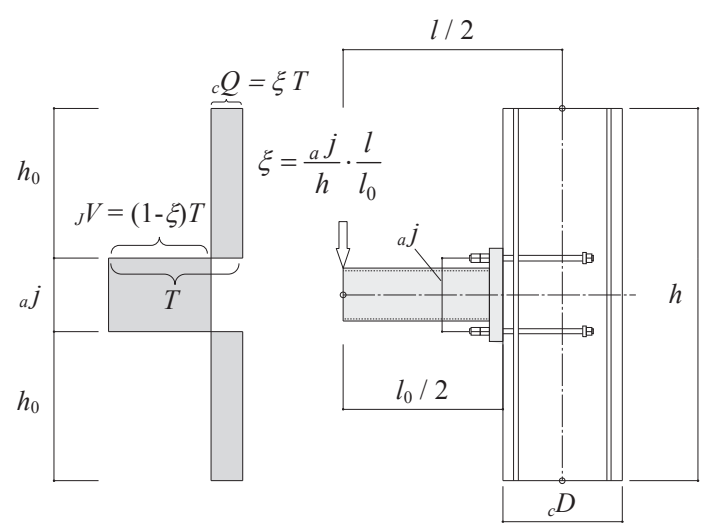

図 $3 \mathrm{RC}$ 部材のせん断力図

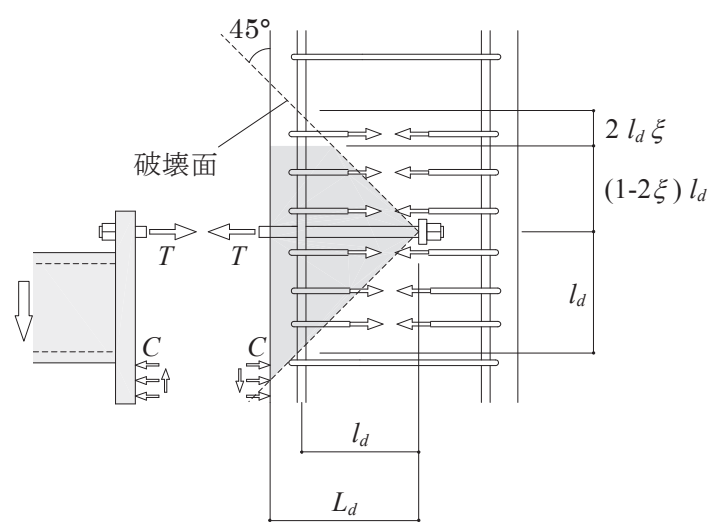

図 $4 \mathrm{RC}$ 部材側の破壊面を貫通するせん断補強筋の効果
壊面を貫通するせん断補強筋は, その一部が接合部パネルに応力を 伝達する役割を担うことに注意する必要がある。図3は，卜字形接 合部の RC部材のせん断力図を示したものである。ここで, $h_{0}$ はC 部材接合端から $\mathrm{RC}$ 部材の反曲点までの距離, $l_{0} / 2$ は RC部材表面から $\mathrm{S}$ 部材の反曲点までの距離である。せん断力図より, アンカーボル トに作用する引張力 $T$ のうち, $\mathrm{RC}$ 接合部パネルにはせん断力 $J$ 養伝 達され, $\mathrm{RC}$ 部材にはせん断力 $c Q$ が直接伝達される。したがって, 図 4に示すように, $\mathrm{RC}$ 部材側の破壊面を貫通するせん断補強筋に伝達 される応力は, $(1-2 \xi) l_{d}$ の範囲の応力が接合部パネル側に, $2 l_{d} \xi$ の範 囲の応力が直接RC部材に伝達されることになる3)。

また, トラス機構は, $L_{d} \fallingdotseq d の$ 場合と同じように形成されると考え られる。

一方, 図2(b)に示すように, 引張側のアンカーボルト近傍に集中 的にせん断補強筋（以下, 集中補強筋という）を配置することによ って, 定着板に作用寸る支圧応力の反力は, 集中補強筋の引張力 ${ }_{a} T_{w}$ としてA点側に伝達される。この応力伝達によって, $\mathrm{RC}$ 部材接合端 では圧縮力 $R_{p}$, 集中補強筋の引張力 ${ }_{a} T_{w}$ および圧縮力 ${ }_{c} C_{a}$ とせん断力 ${ }_{c} Q_{a}$ が釣合系を構成し, 接合部では $L_{d} \fallingdotseq d$ の場合と同様のアーチ機構 が形成されると考えられる。

なお, 定着板直上にRC部材の主筋が配置されるようなアンカーボ ルトの埋込み長さを確保することは, かぶり厚さの確保等を考えれ
ば現実的に困難であると考えられる。したがって, 本論では, $L_{d}<d$ の場合を対象として, 接合部近傍に配置されたせん断補強筋が応力 伝達におよぼす影響を実験的に検討する。

\section{3. 実験}

図5に実験変数を示す。実験は, 実験 I と実験 II よって構成さ れる。実験 I は, 接合部近傍のせん断補強筋が応力伝達におよぼす 影響を調べることを目的とし, 接合部近傍の配筋状況を変数とする 計 4 体の試験体が計画された。

T-A270RN試験体は，接合部近傍にせん断補強筋が配置されてお らず，アンカーボルトの引抜きに伴うコンクリートの抵抗力を調心゙ るための試験体である。T-A270JRO試験体はRC部材側の破壊面内, T-A270JRI試験体はRC接合部パネルにのみせん断補強筋が配置さ れている。T-A270 試験体は, 接合部近傍に2-D10とするせん断補 強筋が $70 \mathrm{~mm}$ の間隔 $\left(p_{w}=0.74 \%\right)$ で配置されている。なお, 各試 験体とも，アンカーボルトの埋込み長さは， $270 \mathrm{~mm}\left(0.6_{c} D\right.$ ア $\mathrm{PC}$ 鋼棒の呼び名の 15 倍）である。一方，実験 II では，アンカーボルト 近傍に配置された集中補強筋が応力伝達におよぼす効果を調べる。 接合部近傍のせん断補強筋の配置状況およびアンカーボルトの埋込 み長さが実験 I のT-A270試験体と同じであるT-270試験体を基準と して，アンカーボルト近傍に集中補強筋を設けたT-270ST試験体，

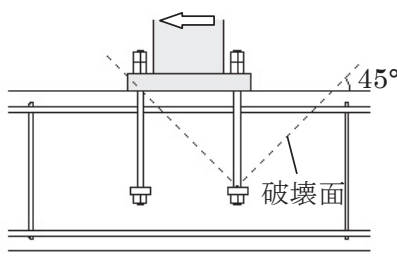

T-A270RN 試験体

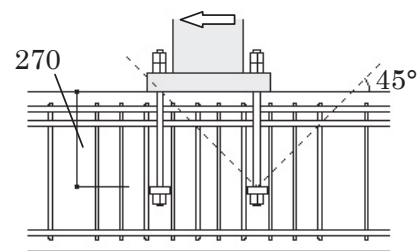

$\mathrm{T}-270$ 試験体

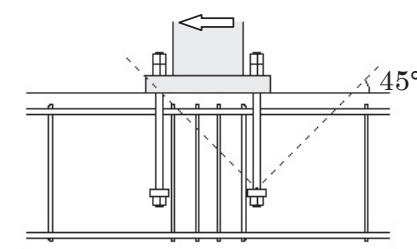

T-A270JRI 試験体

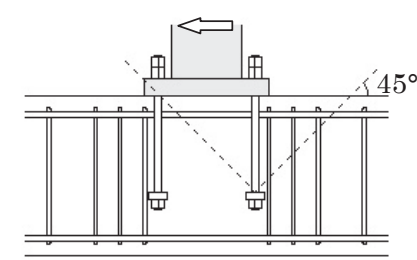

T-A270JRO 試験体

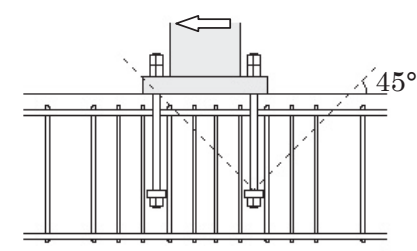

T-A270 試験体

(a) 実験 I $\quad\left(L_{d}=270 \mathrm{~mm}\right)$

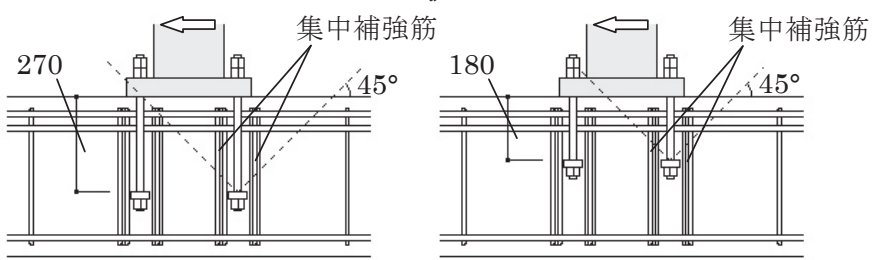

T-180ST 試験体

(b) 実験 II $\left(L_{d}=270 \mathrm{~mm} / 180 \mathrm{~mm}\right)$

図 5 実験変数 


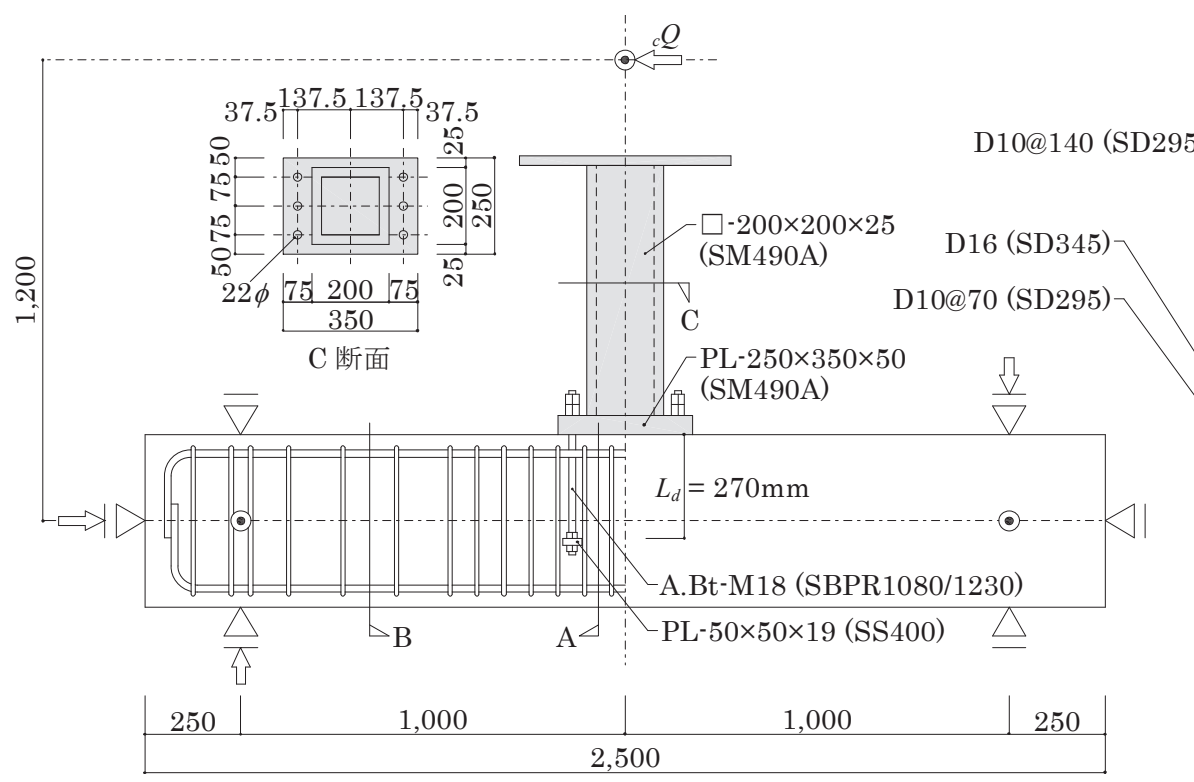

実験 I

実験 II

T-A270 試験体

図 6 試験体詳細

表 1 材料の力学的特性

\begin{tabular}{|c|c|c|c|c|c|}
\hline \multicolumn{2}{|l|}{ 材料 } & $\begin{array}{c}\sigma_{y} \\
\text { 降伏応力度 } \\
\left(\mathrm{N} / \mathrm{mm}^{2}\right)\end{array}$ & $\begin{array}{c}\sigma_{u} \\
\text { 引張強度 } \\
\left(\mathrm{N} / \mathrm{mm}^{2}\right)\end{array}$ & $\begin{array}{c}E_{s} \\
\text { ヤング係数 } \\
\left(\mathrm{N} / \mathrm{mm}^{2}\right)\end{array}$ & 備考 \\
\hline \multirow[b]{2}{*}{ 鉄骨 } & PL25 (SM490A) & 349 & 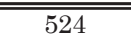 & $2.02 \times 10^{5}$ & \\
\hline & PL50 (SM490A) & 329 & 510 & $1.67 \times 10^{5}$ & \\
\hline \multirow{2}{*}{ 主筋 } & \multirow{2}{*}{ D16 (SD295) } & 375 & 525 & $1.71 \times 10^{5}$ & 1) \\
\hline & & 377 & 585 & $1.87 \times 10^{5}$ & $2), 3)$ \\
\hline \multirow{2}{*}{ せん断補強筋 } & \multirow{2}{*}{ D10 (SD345) } & 355 & 500 & $1.81 \times 10^{5}$ & 1) \\
\hline & & 388 & 545 & $1.74 \times 10^{5}$ & $2), 3)$ \\
\hline アンカーボルト & $17 \mathrm{~mm}$ & 1171 & 1251 & $1.95 \times 10^{5}$ & \\
\hline
\end{tabular}

\begin{tabular}{|c|c|c|c|c}
\hline 材料 & $\begin{array}{c}F_{c} \\
\text { 压縮強度 } \\
\left(\mathrm{N} / \mathrm{mm}^{2}\right)\end{array}$ & $\begin{array}{c}F_{t} \\
\text { 割裂強度 } \\
\left(\mathrm{N} / \mathrm{mm}^{2}\right)\end{array}$ & $\begin{array}{c}E_{c} \\
\text { ヤング係数 } \\
\left(\mathrm{N} / \mathrm{mm}^{2}\right)\end{array}$ & 備考 \\
\hline \hline \multirow{3}{*}{ コンクリート } & 32.4 & 2.75 & $2.39 \times 10^{4}$ & $1)$ \\
\cline { 2 - 6 } & 21.1 & 2.17 & $2.30 \times 10^{4}$ & $2)$ \\
\cline { 2 - 5 } & 23.7 & 2.48 & $2.15 \times 10^{4}$ & $3)$ \\
\hline
\end{tabular}

1）実験 I シリーズ

2) T-270 および T-270ST 試験体

3) $\mathrm{T}-180 \mathrm{ST}$ 試験体

T-270ST試験体と同配筋でアンカーボルトの埋込み長さを $180 \mathrm{~mm}$

（0.4Dかつ PC鋼棒の呼び名の10倍）とする T-180ST試験体の計 3 体が計画された。なお，3体とも $45^{\circ}$ 方向に仮定された破壊面内に 配置されたせん断補強筋量が同じになるように, T-270STおよび $\mathrm{T}-180 \mathrm{ST}$ 試験体は，アンカーボルト近傍に2-D10とする6組の閉鎖型 せん断補強筋が配置されている。

アンカーボルトの埋込み長さについて, 日本建築学会「鋼構造接 合部設計指針」1）では，アンカーボルト径の 20 倍以上を確保する必 要があると示されている。一方, 日本建築総合試験所「機械式鉄筋 定着工法設計指針」4) では, 別途梁主筋の定着長さの規定が設けら れているが, 基本は柱せいの $3 / 4$ 以上とすることが示されている。本 実験では, 前述の接合部の応力伝達機構および抵抗機構の検証に主 眼を置いているため, 接合部の破壊に先行して $\mathrm{S}$ 部材やアンカーボ ルトが降伏することのないように，これらの規定よりもアンカーボ ルトの埋込み長さが小さくなるように設定した。

図 6 は, T-270A 試験体を代表して, 試験体詳細を示したもので ある。実験 I および II の各試験体とも， S 部材は $\square-200 \times 200 \times 25$ (SM490A）とし，エンドプレートは PL-250×350×50（SM490A） である。アンカーボルトは, M18 の PC 鋼棒 (C 種 1 号) が 6 本配 置されている。RC 部材の断面寸法は $300 \times 450 \mathrm{~mm}$ である。主筋は,
実験 I では 8-D16（SD345），実験 II では 10-D16（SD345）として いる。表 1 に使用材料の力学的特性を示す。

実験は, 図 6 に示寸ように, $\mathrm{RC}$ 部材を単純支持し, $\mathrm{S}$ 部材端部 に単調に水平力を負荷するものである。

\section{4. 実験結果とその考察}

図 7 は, 代表して実験 II の各試験体の最終破壊状況を示したもの である。接合部近傍の配筋状況およびアンカーボルトの埋込み長さ にかかわらず, 層間変形角 $R=0.5 \%$ 前後で, 接合部の定着板位置か らエンドプレート圧縮側に向かって接合部パネルに斜めひび割れ (図中の (1) ) が生じた。その後, 変形の増大に伴って, 接合部の斜め ひび割れは RC 部材接合端を越えて RC 部材側に大きく進展した。 $\mathrm{T}-270$ 試験体は， $R=2.0 \%$ までにアンカーボルトの引抜きに伴うコ ーン状ひび割れ（図中の(2)）が生じ， RC 部材上面のコンクリート の浮き上がりが観察された。しかしながら，T-270ST 試験体は，コ ーン状ひび割れは生じているものの, 最終振幅までコーン状ひび割 れの顕著な進展は見られず，接合部パネルの斜めひび割れが卓越し ている。一方， T-180ST 試験体は，R=1.0\%までに生じたコーン状 ひび割れが変形の増大に伴って大きく進展し， $\mathrm{RC}$ 部材上面のコン クリートの浮き上がりも顕著であった。また，T-270 試験体に比心゙ 


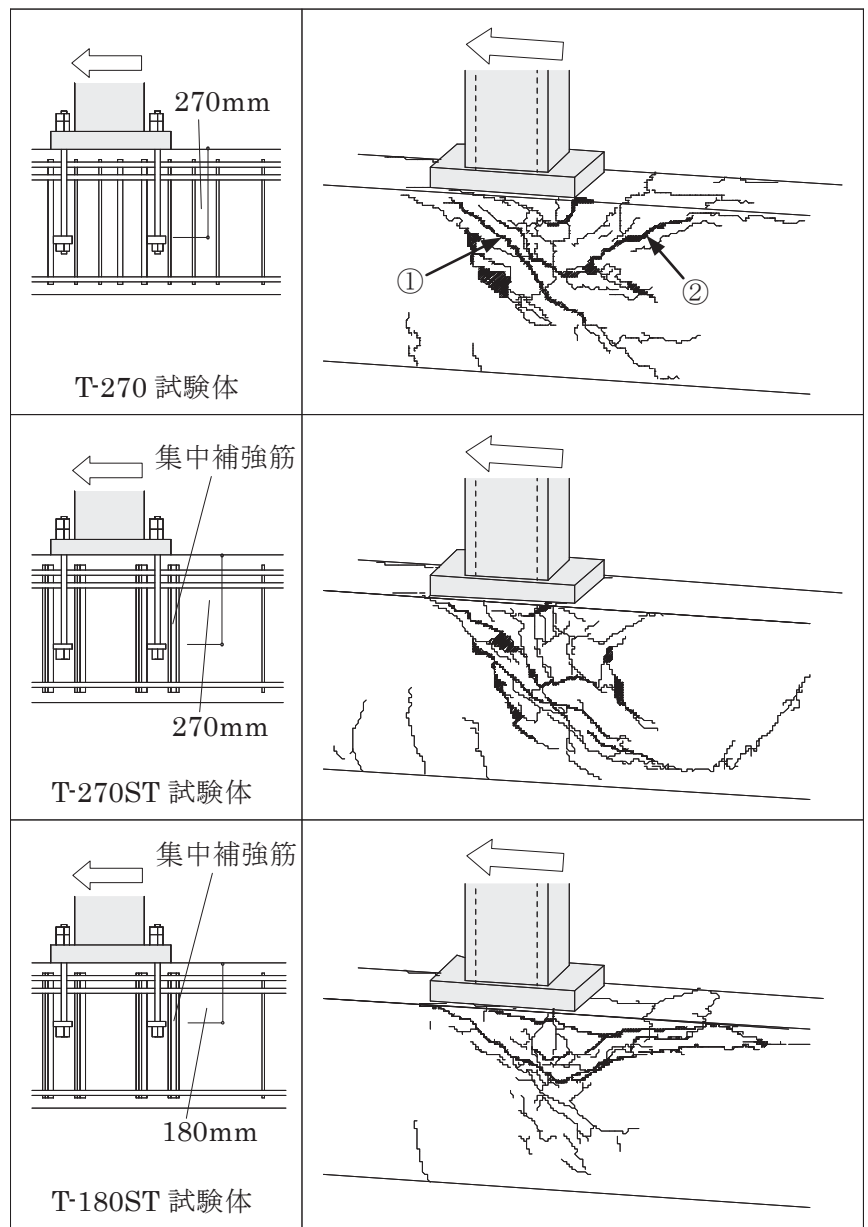

図 7 最終破壊状況（実験 II ）

て, コーン状ひび割れの角度が小さく, $\mathrm{RC}$ 部材の主筋に沿って $\mathrm{RC}$ 部材側へ進展していることがわかる。なお, 実験 I シリーズの各試 験体は，接合部近傍の配筋状況にかかわらず，T-270 試験体とほぼ 同様のひび割れの進展および最終破壊状況を示した。

図 8 に実験 $\mathrm{I}$ の各試験体の荷重 - 変形関係を示す。縦軸は $\mathrm{S}$ 部材 に負荷された荷重 ${ }_{c} Q$, 横軸は層間変形角 $R$ である。各試験体とも, $R=0.5 \%$ 付近で，接合部パネルの斜めひび割れ発生とともに荷重の 低下が見られるが, その後, 変形の増大に伴って荷重が増大してお り, 全体的には, 接合部近傍に配置されたせん断補強筋量の増大と ともに試験体の最大荷重は増加することがわかる。また, せん断補 強筋が $\mathrm{RC}$ 部材側および接合部パネル側にのみ配置された T-A270JRO および T-A270JRI 試験体の荷重 - 変形関係はほぼ等し いことから, 各試験体の最大荷重の差は, 接合部近傍のせん断補強 筋量に関係していることが推察される。

図 9 に実験 II の各試験体の荷重 - 変形関係を示す。ここでは, 各 試験体のコンクリート強度に差異があるため, 縦軸に $\mathrm{S}$ 部材に負荷 された荷重 ${ }_{c} Q$ を $\mathrm{RC}$ 部材接合端の抵抗モーメントに置換し, ${ }_{c} b \cdot{ }_{c} D^{2} \cdot \sigma_{B}$ によって無次元化した值 $m$ をとっている。横軸は層間変 形角 $R$ である。ここで， $\sigma_{B}$ はコンクリートの圧縮強度である。 $\mathrm{T}-270 \mathrm{ST}$ 試験体と T-270 試験体の最大荷重は, 大きな相違が見られ ない。しかしながら, 最大荷重発揮後, T-270 試験体ではコーン状 ひび割れの進展とともに荷重が低下しているのに対して，T-270ST 試験体は，最大荷重をほぼ維持している。これらのことから， $L_{d}=$

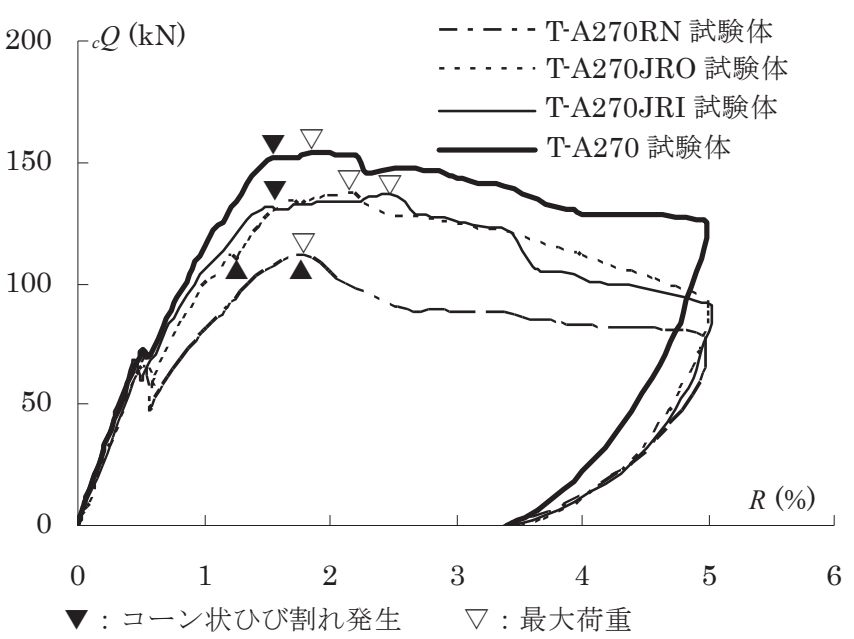

図 8 荷重 - 変形関係 (実験 I )

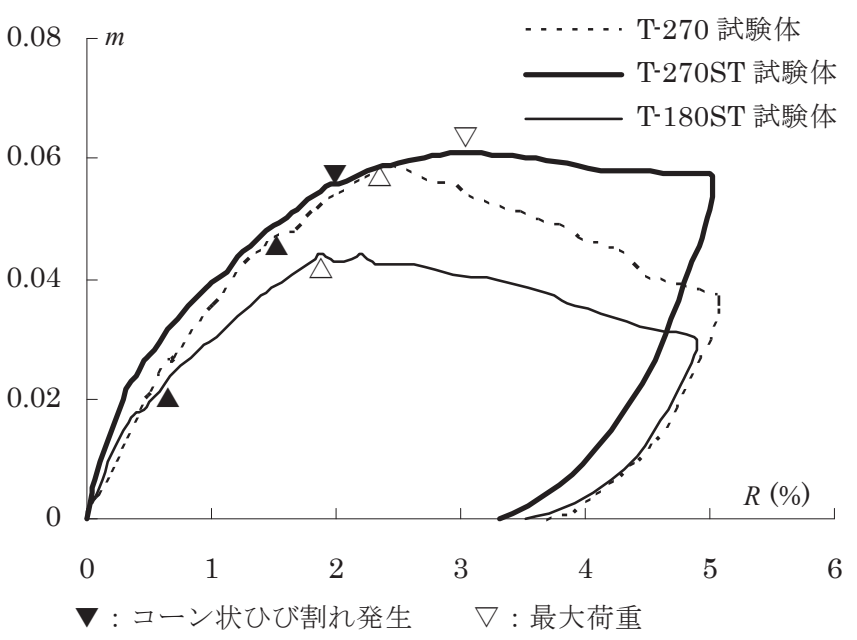

図 9 荷重 - 変形関係（実験 II）

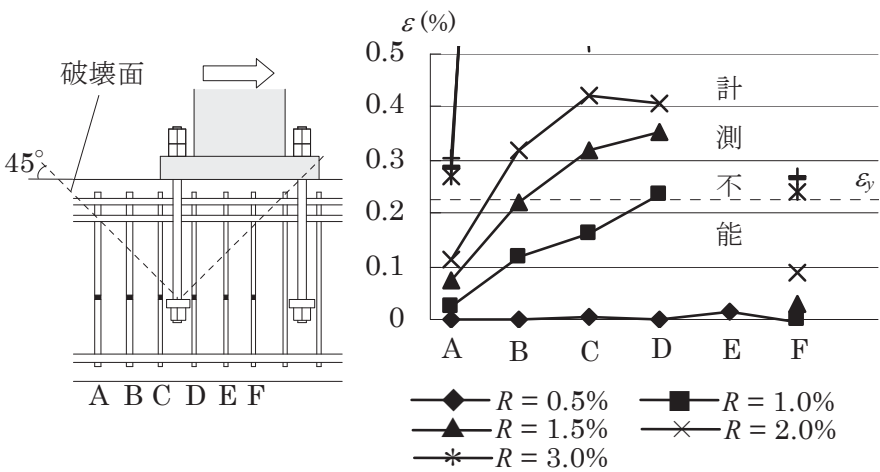

図 10 せん断補強筋の軸ひずみ度分布（T-270 試験体）

$0.6_{c} D$ 程度の場合, 接合部パネルにせん断補強筋を均等に配置する よりも，アンカーボルト近傍に集中的に配置した方が，最大荷重発 揮後のコーン状ひび割れの進展およびそれに伴う荷重の低下を抑制 することがわかる。一方，アンカーボルトの埋込み長さに着目する と, T-180ST試験体の最大荷重は, T-270ST試験体に比べて小さく, 最大荷重発揮後の荷重の低下も顕著である。これらのことから，本 実験の範囲では， $L_{d}=0.4_{c} D$ 程度の場合では，集中補強筋の効果は 期待できないことが推察される。 
図 10 は, T-270 試検体（実験 II）を代表して, 接合部近傍に配置 されたせん断補強筋の軸ひずみ度分布を示したものである。縦軸は 図に示すせん断補強筋の各点の軸ひずみ度 $\varepsilon$, 横軸はひずみゲージ 位置である。また, グラフ中の点線は, せん断補強筋の降伏ひずみ 度 $\varepsilon_{y}$ を示す。実験から得られた軸ひずみ度は, 破壊面内に配置され ているアンカーボルト近傍のせん断補強筋ほど軸ひずみ度が卓越し， アンカーボルトから離れるにつれて小さくなっている。このことか ら，アンカーボルト近傍に集中的にせん断補強筋を配置する方が， 接合部の応力伝達におよぼす効果は大きくなることが示唆される。

\section{5. 接合部の終局耐力の評価}

図 11 は, 図 2 で示された非埋込久接合部の応力伝達機構に立脚 した力学モデルを示したものである。接合部の終局耐力は, アーチ 機構による耐力とトラス機構による耐力を一般化累加することによ って評価できるものとする。このモデルでは, エンドプレートに作 用する圧縮応力の合力 $C$ はアンカーボルト位置に作用するものとし, 接合部の終局耐力の評価に際しては, $\mathrm{S}$ 部材に作用寸るせん断力は 無視する。以下, 一部の記号については, 図 1 に示寸通りである。

アーチ機構による耐力 $M_{A}$ は, $\mathrm{RC}$ 部材接合端の抵抗モーメントに よって表現すると，接合部パネルのコンクリート圧縮束に作用する 圧縮力 $R_{p}$ によって決定される耐力 $M_{a 1}$ と, コーン状破壊時のコンク リートの抵抗力によって決定される耐力 $M_{c f}$, アンカーボルト近傍 に配置された集中補強筋によって決定される耐力 $M_{a w 1}$ および破壊 面を貫通する $\mathrm{RC}$ 部材側のせん断補強筋の引張降伏耐力 $M_{a w 2}$ を累加 して求められる耐力 $M_{a 2}$ によって，(1)式で評価される。

$$
M_{A}=\min \left(M_{a 1}, M_{a 2}\right), \quad M_{a 2}=M_{c f}+M_{a w 1}+M_{a w 2}
$$

圧縮力 $R_{p}$ によって決定される耐力 $M_{a 1}$ は, 接合部パネルのコンクリ 一ト圧縮束のせいを $k_{c} D$ と仮定し, コンクリート圧縮束に作用する 圧縮力 $R_{p}$ は, コンクリートの圧縮強度 $\sigma_{B}$ に達しているものとする と, 図11(a)に基づいて，(2)式で表現される。

$$
R_{p}={ }_{e} b_{p} \cdot k \cdot{ }_{c} D \cdot \sin \alpha \cdot \sigma_{B}
$$

ここで,

$$
\begin{gathered}
\text { 集中補強筋がある場合 }: \sin \alpha=\frac{{ }_{a j}^{j}}{\sqrt{\{(1-k) \cdot D\}^{2}+{ }_{a}^{j} j}} \\
\text { 集中補強筋がない場合 }: \sin \alpha^{\prime}=\frac{{ }_{a j}^{j}+(1-2 \cdot \xi) / 2}{\sqrt{\{(1-k) \cdot D\}^{2}+\left\{{ }_{a} j+(1-2 \cdot \xi) / 2\right\}^{2}}} \\
\xi=\frac{a j}{h} \cdot \frac{l_{0}}{l}
\end{gathered}
$$

$k$ は 0 から 1 の任意の值， $\alpha$ および $\alpha^{\prime}$ は接合部パネルのコンクリー 卜圧縮束と $\mathrm{RC}$ 部材断面とのな寸角, $\sigma_{B}$ はコンクリートの圧縮強度, ${ }_{e} b_{p}$ は接合部パネルの有効幅であり,${ }_{e} b_{p}=\left(b_{c}+{ }_{e p} b\right) / 2$ とする。

この $R_{p}$ を用いて, $\mathrm{RC}$ 部材接合端の抵抗軸力 $N_{a 1}$ と抵抗モーメン ト $M_{a 1}$ を表現すると，（3a）および(3b)式となる。

$$
\begin{aligned}
& N_{a 1}=R_{p} \cdot \sin \alpha \\
& M_{a 1}=R_{p} \cdot \sin \alpha \cdot \frac{(1-k) \cdot{ }_{c} D}{2}
\end{aligned}
$$

縦軸に $\mathrm{RC}$ 部材接合端の抵抗軸力 $N$, 横軸に抵抗モーメント $M$ を とり， $k$ に 0 1 の值を代入して $(3 \mathrm{a})$ および(3b)式を表現すると，圧 縮力 $R_{p}$ によって決定される耐力は, 図 $12(\mathrm{a})$ に示寸耐力 $I_{a 1}$ として求 められる。

アンカーボルトの引抜きに伴うコーン状破壊によるコンクリート の抵抗力は, 「RC 造建物の勒性保証型耐震設計指針・同解説」5)に 示される梁主筋のかき出し定着破壊耐力を参考にして求める。この 抵抗力をアンカーボルトの引張抵抗力 $T_{c f}$ によって表現すれば, (4) 式によって求められる。

$$
T_{c f}=2 \cdot L_{d} \cdot b_{c} \cdot 0.313 \sqrt{\sigma_{B}} \cdot \frac{\sqrt{L_{d}{ }^{2}+{ }_{a} j^{2}}}{{ }_{a} j}
$$

集中補強筋によって決定される耐力は，アンカーボルトの引張力 $T_{a w 1}$ によって表現すると，(5)式で与えられる。

$$
T_{a w 1}=n_{s} \cdot{ }_{a} a_{w} \cdot{ }_{d} \sigma_{w y}
$$

ここで， $n_{s}$ は集中補強筋本数， $a_{a} a_{w}$ は集中補強筋の断面積， ${ }_{a} \sigma_{w y}$ は集 中補強筋の降伏強度である。

破壞面を貫通する $\mathrm{RC}$ 部材側のせん断補強筋によって決定される

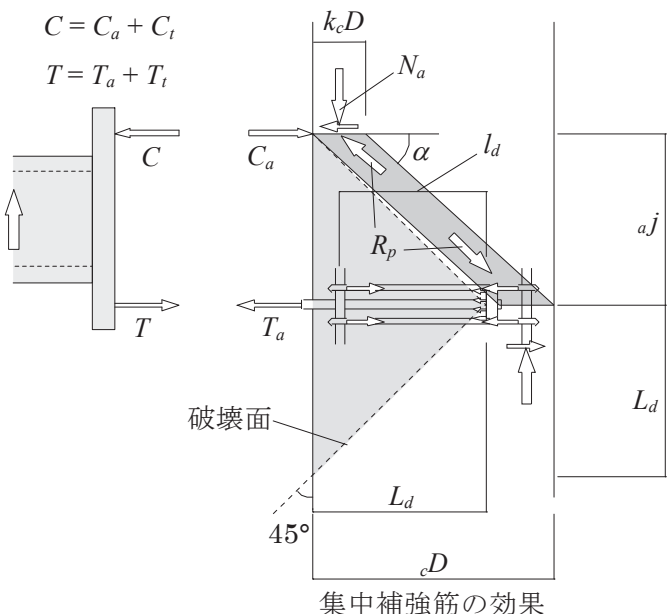

(a) アーチ機構

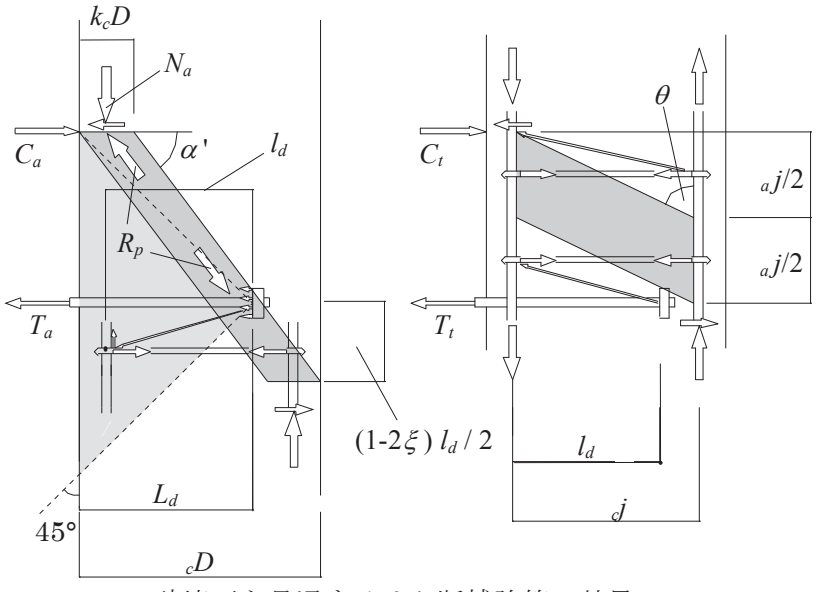

破壊面を貫通するせん断補強筋の効果

図 11 接合部の終局耐力評価モデル 

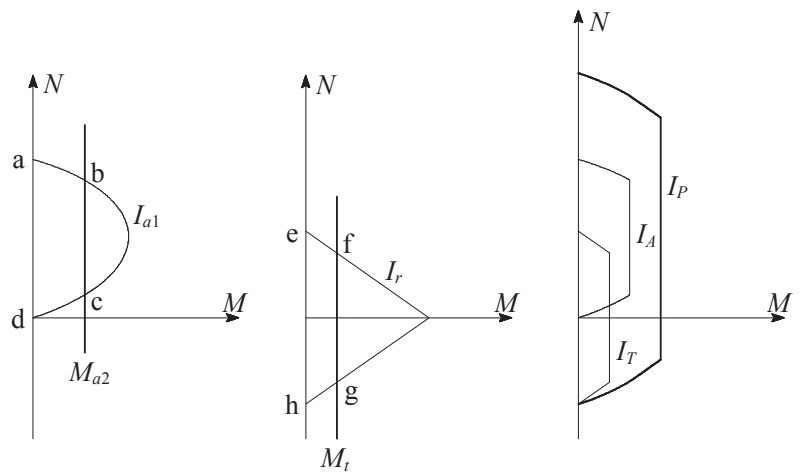

(a) アーチ機構に

(b) トラス機構

（c） 接合部の終局耐力 よる耐力 よる耐力

図 12 非埋め込み接合部の終局耐力の評価

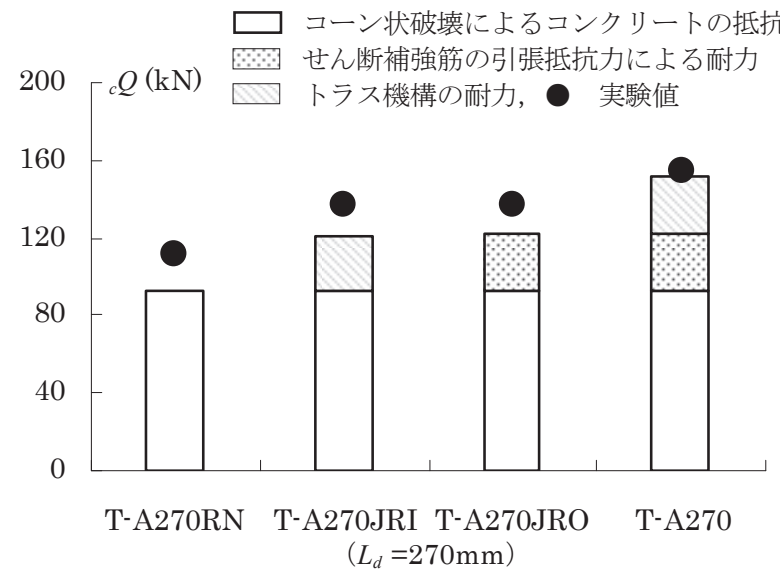

(a) 実験 I

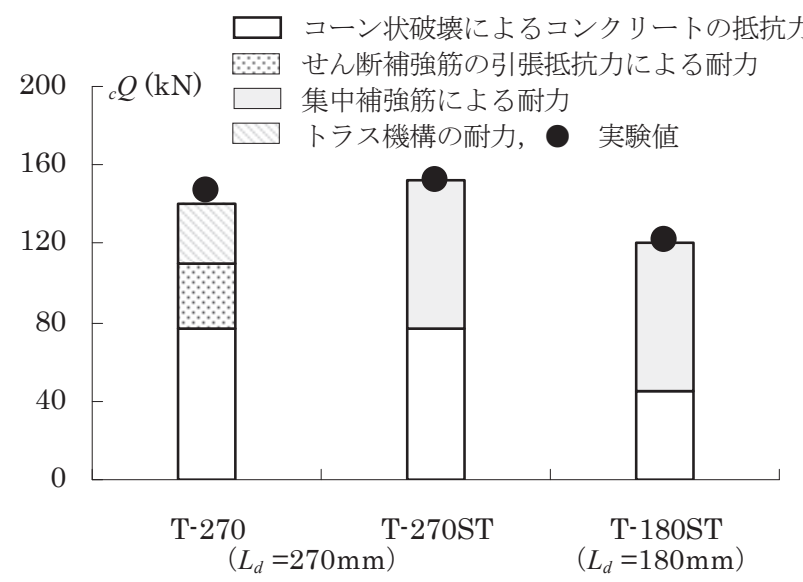

(b) 実験 II

図 13 実験值と計算值の比較（非埋込夕接合部）

耐力 $M_{a w 2}$ は，(6)式によって求められる。

$$
M_{a w 2}=\frac{{ }_{c} p_{w} \cdot{ }_{c} \sigma_{w y} \cdot\left\{(1-2 \cdot \xi) \cdot l_{d}\right\} \cdot b_{e} b_{p}}{\left(h /{ }_{a} j-1\right)} \cdot \frac{\left(h-{ }_{a} j\right)}{2}
$$

ここで, ${ }_{c} P_{w}$ は破壊面を貫通する $\mathrm{RC}$ 部材側のせん断補強筋比, ${ }_{c} \sigma_{w y}$ はせん断補強筋の降伏強度である。

(4)式および(5)式で求められるアンカーボルトの引張抵抗力を $\mathrm{RC}$ 部材接合端の抵抗モーメント $M_{c f}$ および $M_{a w 1}$ に置換し，(6)式で
求められる耐力 $M_{a w 2}$ を累加すれば, (1)式第二項の耐力 $M_{a 2}$ が得られ る。したがって, アーチ機構による耐力は, 図 12(a)に示すように, $I_{a 1}$ のうち $M_{a 2}$ で区切られた abcd の内側の領域によって求められる。

一方，トラス機構による耐力は，接合部パネルに配置されたせん 断補強筋の引張降伏によって決定されるものとすると, 図 11(b)に 基づいて，(7)式によって求められる。

$$
M_{t}=\frac{1}{2} \cdot{ }_{p} p_{w} \cdot \sigma_{w y} \cdot{ }_{a} j \cdot{ }_{e} b_{p} \cdot \frac{\sin \theta}{\cos \theta} \cdot{ }_{c} j
$$

ここで，

$$
\cos \theta=\frac{{ }_{a} j / 2}{\sqrt{L_{d}{ }^{2}+\left({ }_{a} j / 2\right)^{2}}}, \quad \sin \theta=\frac{l_{d}}{\sqrt{L_{d}{ }^{2}+\left({ }_{a} j / 2\right)^{2}}}
$$

${ }_{p} p_{w}$ は接合部パネルのせん断補強筋比， $\sigma_{w y}$ はせん断補強筋の降伏引 張強度, $\theta$ は RC 部材軸とコンクリート圧縮束とのな寸角度である。

トラス機構に入力し得る最大の抵抗力は主筋の耐力によって評価 され, 縦軸に $\mathrm{RC}$ 部材端の抵抗軸力 $N$, 横軸に抵抗モーメント $M$ を とれば, 図 $12(\mathrm{~b})$ に示すように, 主筋の耐力は $I_{r}$ として表現される。 したがって, トラス機構による耐力は, 主筋の耐力 $I_{r}$ のうち, せん 断補強筋によって決定される耐力 $M_{t}$ によって区切られた efgh の内 側の領域によって求められる。

以上より, 非埋込み接合部の終局耐力は, 図 $12(\mathrm{c})$ に示寸ように, アーチ機構による耐力 $I_{A}$ とトラス機構による耐力 $I_{T}$ を一般化累加す ることによって, $I_{P}$ として求められる。

図 13 に実験值と提案された力学モデルに基づいて算出された計 算値の比較を示す。縦軸は $\mathrm{S}$ 部材端部の荷重 $c Q$, 横軸は試験体名で ある。計算の際, アンカーボルトの引張抵抗力によって表現される 耐力は, その応力中心間距離を引張側および圧縮側アンカーボルト の重心間距離としてモーメントに置換した。実験 I について，引張 側アンカーボルトの両側あるいは片側にせん断補強筋が配置されて いない試験体の計算値は, 実験值に対して若干安全側の評価を与え ている。これは, せん断補強筋が配置されていないために, アンカ 一ボルトの引抜きに伴って破壊面内の主筋が曲げ抵抗し，その効果 が計算值に反映されていないことが要因と考えられる。一方，引張 側アンカーボルトの両側にせん断補強筋が配置されている試験体の 計算值は, 実験值を精度よく評価できていることから, 図 11 で示 された接合部の抵抗機構の妥当性が推察される。

\section{6. 機械式定着工法を用いた RC 造柱梁接合部への応用}

図 14 に機械式定着工法を用いた $\mathrm{RC}$ 造柱梁接合部の応力伝達機 構を示す。梁の定着筋に作用する引張力を介して定着筋に生じる付 着力および定着ナットに生じる支圧応力の反力は, $\mathrm{RC}$ 部材断面の 隅角部に配置された主筋に向かう力となり，破壊面を貫通寸るせん 断補強筋の引張力として伝達される。このように, 機械式定着工法 を用いた RC 造柱梁接合部において，梁部材の定着筋をアンカーボ ルト，定着ナット（ロックナット）を定着板とみなし，梁断面をエ ンドプレート断面，柱断面を $\mathrm{RC}$ 部材断面に読み替えれば，その応 力伝達機構は非埋込み接合部と基本的に同じであることから，提案 された接合部の終局耐力評価法を適用できると考えられる。また， これらのことから，アンボンド型あるいはボンド型といったアンカ 一ボルトの種別に依存することなく，本終局耐力評価法を適用でき ると考えられる。 


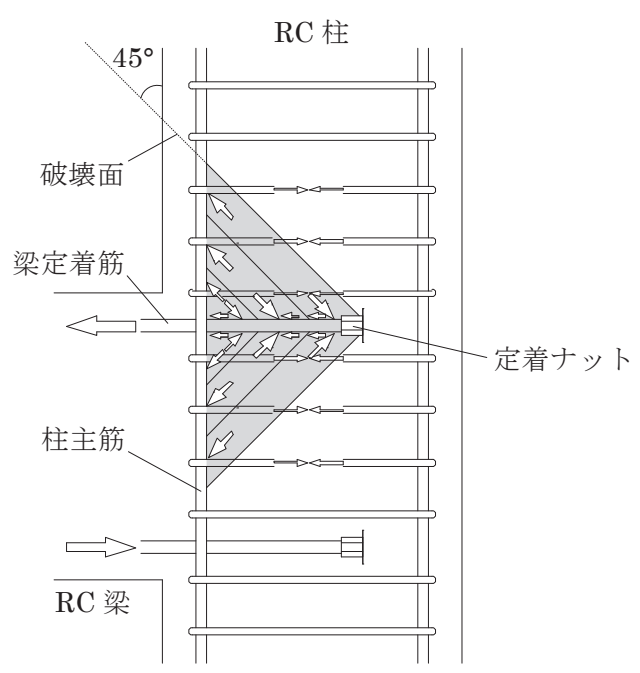

図 14 機械式定着工法を用いた $\mathrm{RC}$ 造柱梁接合部の応力伝達機構

このような観点から, 図 15 は, 機械式定着工法を用いた $\mathrm{RC}$ 造 柱梁接合部に関する既往の実験值と計算值の比較を示したものであ る。縦軸は実験值 $Q_{\text {exp. }}$, 横軸は計算値 $Q_{\text {theo }}$ である。対象とする実験 データは, 機械式定着工法を用いた RC 造柱梁接合部について, 破 壊モードが接合部のせん断破壊あるいは梁主筋のかき出し定着破壊 と報告されている 38 体 6)-17) である。なお, いずれの試験体も, 接 合部パネルおよびその近傍に高強度せん断補強筋が使用されたもの は含まれていない。実験値は, 実験值の計算值に対する比 $\alpha=Q_{\text {exp }}$ ! $Q_{\text {theo. }}$ の $0.812 \sim 1.35$ に分布し, その平均值は 1.07 , 変動係数は 0.132 であり, 提案された耐力評価法によって, 実駼值をほぼ評価できる ことがわかる。

\section{7. 結語}

$\mathrm{S}$ 部材がアンカーボルトを介して RC 部材に結合されるト字形接 合部の耐力評価に関する実験的および理論的検討の結果, 以下の知 見が得られた。

1）接合部の応力伝達機構および抵抗機構が提案された。

2）せん断補強筋をアンカーボルト近傍に集中的に配置した方が, 接合部の応力伝達におよぼす効果は大きい。

3） アンカーボルトの埋込み長さが RC 部材せいの 0.6 倍程度の場 合, アンカーボルト近傍に集中補強筋を配筋することによって, アンカーボルトの引抜きに伴うコーン状破壊の進展を抑制できる。 4）アンカーボルトの埋込み長さが RC 部材せいの 0.4 倍程度の場 合，集中補強筋の効果は小さく，コーン状破壊が卓越する。

5）力学モデルに基づいた接合部の終局耐力評価法が提案され, 計 算值は実験值を概ね評価できることが示された。また，本終局耐 力評価法によって, 機械式定着工法を用いた $\mathrm{RC}$ 造柱梁接合部の 終局耐力を評価することができる。

なお，例えば $\mathrm{S}$ 造露出柱脚のように，ベースプレート直下に柱型 の配筋が設けられるようなディテールに対して, 本終局耐力評価法 を直接適用することはできないため，対象とする接合部ディテール を拡張するとともに，より合理的な非埋込み接合部の配筋法を検討 することが今後の課題である。

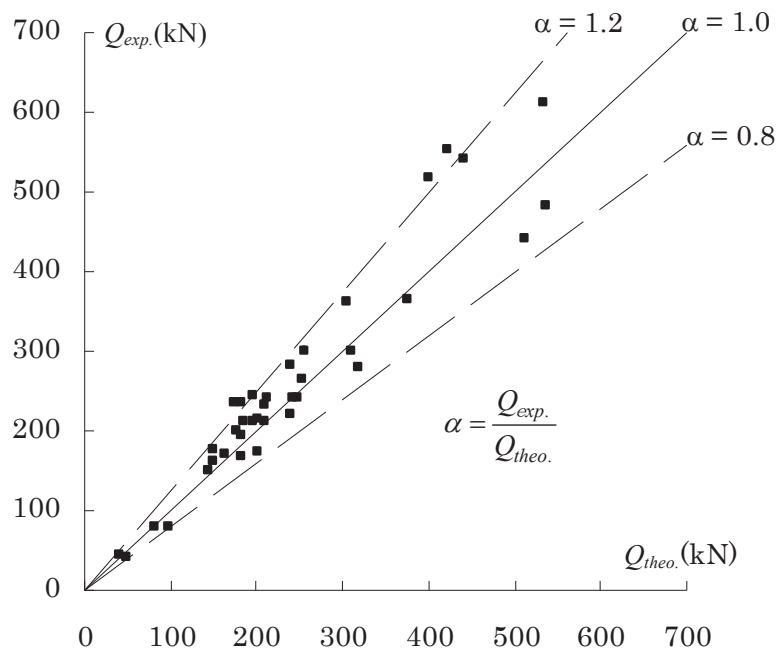

図 15 実験值と計算値の比較（RC 造柱梁接合部）

\section{参考文献}

1） 日本建築学会：鋼構造接合部設計指針，pp.256-269，2006.3

2）馬場望・金井真一・西村泰志 : S 部材がアンカーボルトを介して $\mathrm{RC}$ 部 材に結合される非埋込み接合部の応力伝達機構, 第 8 回複合・合成構造の 活用に関するシンポジウム, pp. 31-1-31-6, 2009.11

3） 中澤春夫, 松崎育弘, 中野克彦： RC 梁主筋の機械式定着部のコーン状 破壊に対するマクロモデル, 日本建築学会構造系論文集, No.575 号, pp.89-96, 2004.1

4） 日本建築学会：鉄筋コンクリート造建物の勒性保証型耐震設計指針・同 解説, p265, 1999

5）日本建築総合試験所：機械式鉄筋定着工法設計指針，pp49-57，2006.1

6）柴田浩二, 今井弘：機械式に定着された外柱梁接合部の構造性能に関寸 る研究, コンクリート工学年次論文集, Vol.22, No.3, pp.1231-1236, 2000

7）田才晃, 川勝康志郎, 清原俊彦, 窪田敏行 : 梁主筋を機械式定着した外 部柱・梁接合部のせん断性状（その 1$)$ （その 2 ), 日本建築学会大会学術 講演梗概集 C-2，pp.857-860，2000.9

8）中澤春生，坂口昇，浅井政宏：主筋を機械式定着した鉄筋コンクリート 造柱梁接合部の構造性能に関する実験, コンクリート工学年次論文集,

Vol.24, No.2, pp.847-852, 2002

9）竹内博幸，中村一彦，早川邦夫，市川昌和：円形定着板により機械式定 着されたト形接合部に関する実験的研究, コンクリート工学年次論文集, Vol.25, No.2, pp.913-918, 2003

10）鬼海正臣，今井弘，カストロ・ホワン・ホセ：機械式に定着された外柱 梁接合部の構造性能に関する研究, コンクリート工学年次論文集, Vol.25, No.2, pp.907-912, 2003

11）長谷川勇樹, 藤本武人, 清原俊彦, 田才晃 : 梁主筋を機械式定着した高 強度鉄筋コンクリート造外柱梁接合部の構造性能, コンクリート工学年次 論文集, Vol.27, No.2, pp.373-378, 2005

12）田畑卓，西原宽： RC 造卜・ $\mathrm{T} ・ \mathrm{~L}$ 形柱梁接合部のせん断および定着性 状, コンクリート工学年次論文集, Vol.23, No.3, pp.373-378, 2001

13）宮内靖昌，佐々木照夫，鴻野良太，村井和雄：柱主筋を圧接コブ定着と した $\mathrm{RC}$ 架構の力学的性状に関する研究, コンクリート工学年次論文報告 集, Vol.21, No.3, pp.313-318, 1999

14）足立将人, 益尾潔: 梁主筋を機械式定着および U 型定着した $\mathrm{RC}$ 造卜形 接合部の抵抗機構, コンクリート工学年次論文集, Vol.29, No.3, pp.217-222, 2007

15）下中裕史, 崔建宇, 内田貴之, 藤井栄 : 鉄筋コンクリート $\mathrm{T}$ 字型, $\mathrm{L}$ 字 型柱・梁接合部のせん断耐カ, コンクリート工学年次論文報告集, Vol.19, No.2, pp.1023-1028, 1997

16）崔建宇，藤井栄，渡辺史夫： $\mathrm{L}$ 字形及び $\mathrm{T}$ 字形接合部のせん断耐力に及 ぼす接合部の配筋ディテールの影響，コンクリート工学年次論文集， Vol.23, No.3, pp.397-402, 2001

17）大和田義正, 隈澤文俊, 太田勤, 小杉雅男, 新藤健太, 小曽根茂雄 : 機 械式定着金物を柱頭柱主筋の定着に使用した L 字形, $\mathrm{T}$ 字形接合部の耐力 と変形性能, 日本建築学会大会学術講演梗概集 C-2, pp.257-258, 2001.9 